sounds heavy. Don't be fooled. There is a jolt on every page and a laugh in every sketch.

Your organization, your office, you yourself are in each chapter. Topics are too numerous to cover here, but some that come to mind are: the jargon of business letters; the ineffectiveness of public relations; the gobbledygook of many speeches; office grapevines; caste system in offi ' $s$; the symbols of caste; the demands of business on private lives; and the "social engineers" who aim at "group harmony" by eliminating "individualism". (From this last it seems that George Orwell's 1984 was here in 1952.)

If, as our latest conference theme suggests, foresters should be selling forestry to the nation, chapters in this book dealing with business selling itself to the public should be required reading. Here a point is made that some of us have suspected for some time. Most people are from Missouri. Floods of words are often ignored. Show people with their own eyes if you want to make converts.

After circulating this book among friends I estimate that two evenings will finish it if you can manage to lay it down at all.

R. Y. EDWARDS

\title{
Forest Fertilization
}

By D. P. White and A. L. Leaf. A bibliography, with abstracts, on the use of fertilizers and soil amendments in forestry. World Forestry Series Bulletin No. 2. Published by State University College of Forestry, Syracuse University, Syracuse 10, New York, U.S.A.

As Professor Heiberg points out in the introduction to this bulletin, with the exception of forest nurseries the use of fertilizers in forestry has been relatively limited.

Unfortunately many foresters, in Canada at least, have until quite recently tended to disregard the demands which trees make on the soil for nutrients. It is becoming readily apparent, however, that an understanding of tree rutrition is fundamental in the solving of many of the problems which arise in the establishment and subsequent growth of our stands.

Foresters will find this bulletin particularly useful since abstracts are included for the majority of the titles. The index has thoughtfully been compiled so that a reader interested in specific topics such as nitrogen, nursery soil management, organic amendments, etc., will find under these headings a list of the papers dealing with such subjects. Every forester interested in the growth of trees should have a copy.

K. A. ARmson

\section{CURRENT PUBLICATIONS GENERAL}

Anon. Annual report of the Newfoundland Forest Protection Association 1957, 79 pp.

Anon. Annual report on forest research, 1957. Dept. of Northern Affairs and National Resources, Forestry Branch, Ottawa, Canada, 78 pp. 
Anon. Commonwealth Agricultural Bureaux Twenty-Eighth Annual Report of Executive Council. 1956 \& 1957, 47 pp.

Anon. Report of the chief of the Forest Service 1956, U.S.D.A. Washington, D.C., $32 \mathrm{pp}$.

Anon. 1957. A guide to the Coweeta Hydrologic Laboratory U.S.D.A. Southeastern Forest Exp. Sta., 40 pp.

Anon. Statement by the Forestry Commission of Great Britain prepared for the British Commonwealth Forestry Conference. 1957, 24 pp.

Anon. 1956. Forest fire protection abstracts Vol. 7, No. 1, Forestry Branch, Dept. of Northern Affairs and National Resources, Ottawa, 29-44 pp.

Anon. 1957. Forest fire protection abstracts Vol. 8, No. 1, Forestry Branch, Dept. of Northern Affairs and National Resources, 51-68 pp.

Forestry Branch, Dept. of N. Affairs and National Resources. 1957. Semiannual report April-September 1957 of Forest Products Laboratories of Canada, 70 pp.

Gilden, E. 1957. Facts and figures about California Christmas trees 1956, $19 \mathrm{pp}$.

\section{MANAGEMENT}

Basham, J. T. 1957. The deterioration by fungi of jack, red, and white pine killed by fire in Ontario. Contribution 335, Div. of. Forest Biology, Science Service, Dept. of Agriculture, Ottawa, $172 \mathrm{pp}$.

Cramer, O. P. 1957. Forest fire weather in western Oregon and western Washington in 1957, Res. Note 154, Pacific Northwest Forest and Range Exp. Sta., Portland, Oregon, 9 pp.

Cramer, O. P. 1957. Test of wind predictions for peak fire-danger stations in Oregon and Washington. Research Paper 22, Pacific Northwest Forest \& Range Exp. Sta., Portland, Oregon, 41 pp.

Cramer, O. P. 1957. Frequency of dry east winds over Northwest Oregon and Southwest Washington. Research Paper 24, Pacific Northwest Forest \& Range Experiment Sta., Portland, Oregon, 19 pp.

Dils, Robert E. 1957. Watershed management research needs in the forests of the Lake States, Department of Forestry, Michigan State University, East Lansing, Mich. 35 pp.

Doyle, J. A. 1957. Effect of tree size of spruce and balsam fir on harvesting and conversion to lumber in Nova Scotia. F. P. L. Tech. Note 5, Forest Products Laboratories of Canada, Ottawa. $30 \mathrm{pp}$.

Ewan, H. G. 1958. Some effects of temperature extremes on Saratoga spittlebug populations. Tech. 519, Lake States Forest Exp. Sta. St. Paul, Minn. 2 pp.

Gaylord, George \& Roe, E. I. Tests of some chemicals for grass control on firebreaks. Tech. Note 516, Lake States Forest Exp. Sta. St. Paul, Minn. 2 pp.

Gaylord, George \& Roe, E. I. 1958. Sodium borates show promise for grass control, Tech. Note 515, Lake States Forest Exp. Sta., St. Paul, Minn. 2 pp. 
Hayes, G, L. and Stein, W. I. 1957. Eliminating blister rust cankers from sugar pine by pruning, Res. Note 151, Pacific Northwest Forest and Range Exp. Sta., Portland, Oregon. 8 pp.

Hesterberg, G. A. 1957. Deterioration of sugar maple following logging damage. Sta. Paper 51, Lake States Forest Exp. Sta., St. Paul, Minn. $58 \mathrm{pp}$.

Larsen, A. T. \& Buckhorn, W. J. 1957. Visual aids for aerial observers on forest insect surveys. Res. Note 149, Pacific Northwest Forest and Range Exp. Sta., Portland, Oregon. 4 pp.

Seely, H. E. 1957. Forest inventories in Canada, Misc. Pub. No. 8, Dept. of Northern Affairs and National Resources, Forestry Branch, Ottawa. 11 pp.

Thomas, G. M. 1957. Climate and growth rate as related to an outbreak of silver fir beetles, Res. Note 150, Pacific Northwest Forest \& Range Exp. Sta., Portland, Oregon. 5 pp.

\section{SILVICULTURE}

Arbogast, Carl, Jr. 1957. Marking guides for Northern hardwoods under the selection system. Sta. Paper 56, Lake States Forest Exp. Sta., St. Paul, Minn. 20 pp.

Atkins, E. S. 1957. Light measurement in a study of white pine reproduction, Forest Research Div. Technical Note. 60, Forestry Branch, Dept. of Northern Affairs and National Resources, Ottawa. $18 \mathrm{pp}$.

Blyth, A. W. 1957. The effect of partial cutting in even-aged lodgepole pine stands, Forest Research Division, Tech. Note 61, Forestry Branch, Dept. of Northern Affairs and National Resources, Ottawa. $14 \mathrm{pp}$.

Brinkman, Kenneth A. 1957. Silvical characteristics of black oak, Miscellaneous Release 19, Central States Forest Exp. Sta. Columbus, Ohio. 14 pp.

Engle, LaMont G, and Williams, Robert D. 1957. Scarifying seedbed boosts yellow-poplar germination. Station Note 110, Central States Forest Experiment Sta., Columbus, Ohio. 2 pp.

Guilkey, Paul C. 1957. Silvical characteristics of American elm, Station Paper 54, Lake States Forest Experiment Sta., St. Paul, Minn. 19 pp.

Merz, Robert W. 1957. Silvical characteristics of shellbark hickory, Miscellaneous Release 18, Central States Forest Experiment Sta., Columbus, Ohio. $14 \mathrm{pp}$.

Minckler, Leon S. 1957. Silvical characteristics of pin oak, Miscellaneous Release 20, Central States Forest Experiment Station, Columbus, Ohio. $10 \mathrm{pp}$.

Miner, N. H. and Knauss, A. C. 1957. Snow interception, accumulation, and melt in lodgepole pine forests in the Blue Mountains of eastern Oregon. Res. Note 153, Pacific Northwest For. \& Range Exp. Sta., Portland, Oregon, $4 \mathrm{pp}$.

McQuilkin, W. E. 1957. Frill treatment with 2-4-5-T and 2-4-D effective for killing northern hardwoods. Station Paper 97. Northeastern Forest Experiment Sta., Upper Darby, Pa. 18 pp. 
Nienstaedt, Hans. 1957. Silvical characteristics of white spruce, Station Paper 55, Lake States Forest Exp. Sta., St. Paul, Minn. 23 pp.

Roe, E. I. 1957. Silvicultural characteristics of tamarack, Station Paper 52, Forest Service Lake States Forest Exp. Sta. St. Paul, Minn. 22 pp.

Ruth, Robert H. 1957. Ten-year history of an Oregon Coastal Plantation, Research Paper 21, Pacific Northwest Forest and Range Experiment Sta., Portland, Oregon. $15 \mathrm{pp}$.

Sander, Ivan L. 1957. Disking increases shortleaf pine reproduction, But . . . Station Note 111, Central States Forest Experiment Station, Columbus, Ohio. 2 pp.

Schubert, G. H. 1957. Silvical characteristics of incense-cedar, Tech. Note 18, Calif. Forest and Range Exp. Sta. 14 pp.

Stein, William I. 1957. A successful direct seeding of sugar pine, Research Paper 25, Pacific Northwest Forest \& Range Experiment Station, Portland, Oregon. $19 \mathrm{pp}$.

Struble, G. R. 1957. The fir engraver - a serious enemy of western true firs, Production Research Report No. 11, Calif. Forest \& Range Exp. sta. $18 \mathrm{pp}$.

Trimble, George R. Jr. 1957, Chaff seeding does not inhibit tree reproduction Forest Research Notes 77, Northeastern Forest Exp. Sta., Upper Darby, Pa. 2 pp.

Worthington, N. P. 1957. Silvical characteristics of red alder, Silvical Series No. 1, Pacific Northwest Forest and Range Exp. Sta., Portland, Oregon. $15 \mathrm{pp}$.

Wright, Jonathan W. \& William J. Gabriel 1957. Effects of continuous bagging of white pine cones Station Paper 99, Northeastern Forest Experiment Sta., Upper Darby, Pa. 5 pp.

\section{UTILIZATION}

Aaron, J. R. 1957. The use of home-grown timber in packaging and materials handling, Forest Record No. 35, Forestry Commission, London. $31 \mathrm{pp}$.

Anon. 1957. Loggers handbook, Vol. XVII, published by the Pacific Logging Congress, 616 American Bank Building Portland 5, Oregon. 15 pp.

Anon. 1956. Strength and related properties of woods grown in Canada, F.P.L. Tech. Note 3, Dept. of Northern Affairs and National Resources, Ottawa. 11 pp.

Clarke, E. H. and Knauss, A. C. 1957. Veneer recovery from peeler-grade Douglas fir logs in western Washington, Res. Note 152, Pacific Northwest Forest \& Range Exp. Sta., Portland, Oregon. 5 pp.

Clarke, E. H. and Knauss, A. C. 1957. Veneer recovery from Douglas fir logs, Research Paper 23, Pacific Northwest Forest and Range Exp. Sta., Portland, Oregon. $13 \mathrm{pp}$.

Doyle, J. A. \& Bender, F. 1957. Wood Residues as pulp material and developments in wallboard production. F.P.L. Tech. Note 6, Dept. of Northern Affairs and National Resources, Ottawa. 19 pp. 
Hamilton, L. S. \& Gordon R. Cunningham. 1957. Longer life for wood in your fencelines and vineyards. Cornell Extension Bulletin 987. Cornell University, Ithaca, New York. 23 pp.

Hampf, Frederick E. 1957. Production and sale of charcoal in the Northeast. Station Paper 100, Northeastern Forest Exp. Sta., Upper Darby, Pa. 14 pp.

Horn, Arthur G. 1957. A record of the timber cut from forests of the Lake States - 1954. Station Paper 53, Lake States Forest Experiment Station, St. Paul, Minn. 47 pp.

James, Lee M. 1957. Resurvey of Christmas tree marketing in Michigan, Special Bulletin 419, Michigan State University Agricultural Experiment Sta., Dept. of Forestry East Lansing. 41 pp.

Larson, P. R. 1957. Effect of environment on the percentage of summerwood and specific gravity of slash pine, Yale University School of Forestry Bulletin No. 63, New Haven, Conn. 78 pp.

McCoy, E. Wesley. 1957. How to minimize the effects of tension wood in cottonwood, Station Note 103, Central States Forest Exp. Sta., Columbus, Ohio. 2 pp.

May, R. H. Wood charcoal in California, Calif. For. and Range Exp. Sta. Forest Survey Release No. 28, September 1957.

Page, R. H. and Carter, R. M. Heavy losses in air seasoning Georgia pine and how to reduce them. Station Paper 85, Southeastern Forest Experiment Sta., Asheville, N.C. 20 pp.

Thornton, Philip L. 1957. Veneer-log production and consumption in the Central States-1956. Station Note 112, Central States Forest Exp. Sta., Columbus, Ohio. 2 pp.

Warner, John R. 1958. Miscellaneous manufacturing industries in the Twin Cities as users of wood, Tech. Note 518, Lake States Forest Exp. Sta., St. Paul, Minn. 2 pp.

Warner, John R. 1958. The Twin Cities lumber and wood products industries as users of wood. Tech. Note 517, Lake States Forest Exp. Sta., St. Paul, Minn. 2 pp.

Todd, A. S. Jr. and Anderson, W. C. An appraisal of methods for salvaging small sawmill residues in the Southeast, Station Paper 84, Southeastern Forest Exp. Sta. 37 pp.

\section{EMPLOYMENT}

For your convenience the Forestry Chronicle offers a free employment service. Prospective employers or applicants should write to Mr. George A. Sinclair, Forest Ranger School, Dorset, Ontario, who will prepare applications for publication.

Positions are available with the Federal Department of Northern Affairs and National Resources in the following fields: Tree Physiology, Forest Ecology, Silviculture and Ecology, Mensuration, Forest Inventory Research, Forest Fire Research, Soils Research, Forest Surveys. Salary range $\$ 4,560-$ $\$ 7,320$. For detailed information see Civil Service Commission of Canada information circular No. 58-1450. 